\title{
Factors affecting the propensity of academic researchers in Mexico to become inventors and their productivity
}

\author{
Factores que afectan la propensión de los investigadores académicos \\ de México de ser inventores y su productividad
}

\author{
Alenka Guzmán*, Nallely Molina Velasco, \\ Guadalupe Calderón Martínez
}

Universidad Autónoma Metropolitana, México

Received November 13, 2017; accepted July 26, 2018

Available online November 23, 2018

\begin{abstract}
We aim to answer the following research questions: Which is the propensity of Mexican Research National System -SNI- researchers from universities and institutes to become inventors in patents granted to their institutions? What are the personal, institutional and innovation nature factors which have influence in such propensity? Which factors favor the inventive productivity of the academic inventors? According to the outcomes of three econometric models proposed, using micro data of USPTO patents during 19802013 and the SNI researchers individual and institutional data, our main findings are: the SNI researchers propensity of being inventors of their institutions' patents is marginal but it is higher when they belong to institutions with an intellectual property regulation. Also, this propensity is associated with: the researcher's age and its SNI level, as personal factors; the institution size and the PhD quality programs approved by CONACYT, as institutional factors; finally, technological amplitude, invention scope, the technological collaboration and the importance of the invention, as factors of the innovation nature. While, the research team mixed of women and men and the technology transfer office have not still influence in the pip. Finally, we have tested that the age has influence in the inventors' productivity in a positive sense and the square_age affects in a negative way. Also, the invention scope and the technological collaboration, have a positive impact. But not, the level of SNI researchers-inventors and the SNI scientific research area, and neither the $\mathrm{PhD}$ academic quality programs.
\end{abstract}

\footnotetext{
* Corresponding author.

E-mail address: alenka.uami@gmail.com (A. Guzmán)

Peer review under the responsibility of Universidad Nacional Autónoma de México.
} 
JEL code: $\mathrm{O} 31, \mathrm{O} 34$

Keywords: Researchers propensity to innovate; propensity factors; Mexican universities; SNI-CONACYT researchers.

\section{Resumen}

Nos proponemos responder las siguientes preguntas de investigación: ¿Cuál es la propensión de los investigadores del Sistema Nacional de Investigación -SNI- de universidades e instituciones de ser inventores de patentes concedidas a sus instituciones -pip-? ¿Qué factores personales, institucionales y de la naturaleza de la innovación se asocian a tal propensión? ¿Qué factores favorecen la productividad inventiva de los investigadores académicos? Conforme a los resultados de los tres modelos econométricos propuestos, utilizando micro datos de USPTO patentes durante 1980- 2013 y los datos individuales e institucionales de los investigadores del SNI, nuestros principales hallazgos son: la pip es marginal pero mayor cuando ellos pertenecen a instituciones con regulación de propiedad intelectual. Tal propensión se asocia con la edad de los investigadores y su nivel del SNI, como factores personales; el tamaño de la institución y los programas de doctorado de calidad reconocidos por CONACYT, como factores institucionales; finalmente la amplitud de la invención, la colaboración tecnológica y la importancia de la invención, como factores de la naturaleza de la innovación. Mientras, que los equipos de investigación mixtos de mujeres y hombres y la transferencia tecnológica no tienen aún influencia en el pip. Con respecto a las variables que tienen influencia en la productividad de los inventores se prueba que la edad la tiene en un sentido positivo y la edad al cuadrado en un sentido negativo; así también, la amplitud de la invención y la colaboración tecnológica tienen un efecto positivo. Pero no así, el nivel de SNI de los investigadoresinventores, su área científica del SNI, y los programas doctorales de calidad.

Código JEL: O31, O34

Palabras clave: Propensión de los investigadores a innovar; factores de la propensión; universidades mexicanas; investigadores de SNI-CONACYT.

\section{Introduction}

Specialized economic literature has analyzed the relevance of scientific and technological knowledge generated in universities that contributes to the technological, economic and social development of countries (Trajtenberg, Henderson and Jaffe, 2002; Libecap, 2005; Yusuf and Nabeshima, 2007). Specific influence has been placed on the study of knowledge flows between academia and companies (Agrawall, 2001; Jaffe and Trajtenberg, 2002). Furthermore, countries have incorporated regulations aimed at fostering innovation in universities and promoting the transfer of technology to the productive sector (Mowery, Nelson, Sampat and Ziedonis, 2004; Henderson, Jaffe and Trajtenberg, 1998), with the active participation of government (Etzkowitz and Leydersdorff, 1995 ${ }^{\text {). }}$

\footnotetext{
${ }^{1}$ Since the beginning of the sixties, the theory of knowledge economy has delved deeply into the analysis of the complex dynamic of relationships between knowledge and production. After describing the different stages and missions that the university has passed through (Etzkowitz et al., 2000; Etzkowitz, 2003), in its current third mission (Bueno and Casani, 2007; Gibb, 1993; Sheen, 1992), it is identified as a basic institution for the transfer of R\&D and knowledge (Gibbons, Limoges, Nowotny, Schwartzman and Trow, 1994; Etzkowitz, Webster, Gebhardt and Terra, 2000; Schulte, 2004). The university extends its action to entrepreneurship (Clark, 1998; Gibbons, 1998), aimed at the commercial-
} 
Diverse empirical studies, especially in industrialized countries (Foray, 2007; Wolfe, 2007) and some developing countries (Zuniga, 2011) have opened the way to understanding the different factors that are involved in the processes of innovation in universities and institutions, as well as the circumstances that favor inventors to create new technological ideas (Gay, Lathan, and Le Bas, 2005; Lissoni, Pezzoni, Poti and Romagnosi, 2013). Several of them have focused their studies on the analysis of patents, revisiting the tradition of economists like Schmookler (1962), Griliches (1984), Jaffe, Trajtenberg and Henderson (1993) and Jaffe and Trajtenberg (2002). The different methodological proposals show great potential for explaining the different specific phenomenon through the use of data contained in patents. There has been growing concern in Mexico to study the contribution of academics and the transfer of technology (De Gortari, 1996), the interaction channels between universities and industry (Dutrénit, De Fuentes and Torrres, 2010) and, in particular, using patents, on the management of university patents (Calderón, 2013); regarding the factors that explain the university-company link (Guzmán, Acatitla and Vázquez, 2015). However, it is worth putting inventors and what explains their propensity for invention under the microscope (Stezano and Millán, 2014). In this case we limit ourselves to the researchers of the National System of Researchers (Sistema Nacional de Investigadores, SNI for its acronym in Spanish) that are affiliated with the universities and institutes of Mexico. After estimating the propensity of investigators to be inventors of patents of advanced education and research institutions of Mexico, it is argued that the contribution of this work lies in the identification of the factors that are associated with this propensity and the estimation of the magnitude of the effects for the purpose of proposing scientific and technological policies that will help boost the inventive potential of researchers. This was possible through the two econometric models proposed, using micro-data from patents, and information from the researchers and institutions in the framework of the theoretical and empirical literature of the knowledge and innovation economy, particularly that relative to university inventors-researchers.

The overall objective of this research is twofold. First, estimate the probability of the participation of researchers of the National System of Researchers (SNI for its acronym in Spanish) of Mexico in the inventions patented by the universities and institutes they are affiliated with over the period of 1980-2013. Second, analyze the factors that influence this propensity.

We ask ourselves: What is the probability of SNI researchers becoming inventors in the institutions they are affiliated with? And what factors related to the individual, the institution and the nature of the innovation influence the propensity of researchers to develop inventions patented by their institutions? Which factors have influence on the productivity of academic inventors?

The hypothesis that we set out is that the probability of SNI researchers becoming inventors of patents for universities or research institutions is still low, although it is higher in institutions with a patenting pathway. Such propensity is expected to be influenced by the following factors: i) the individuals (age, gender, professional specialization, sNI level); ii) the institutional (size of the institution, number of doctorate programs in the National Postgraduate Quality Program ${ }^{2}$ and regulation of intellectual property) and, iii) the elements that characterize the inventive activity performed (size of the inventor team, accumulation of technological knowledge, academia-

ization of technology. The Triple Helix approach studies how to organize university-government-industry relations, (Etzkowitz and Leydersdorff, 1995).

${ }^{2}$ PNPC for its acronym in Spanish, Programa Nacional de Posgrado de Calidad. 
industry links, the importance of the invention, number of novelties generated, technological scope and technological collaboration with other institutions or firms). Furthermore, the productivity of academic inventors is expected to be associated positively with: the age, the level of SNI researcher, the number of doctorate programs in the National Postgraduate Quality Program in the academic inventor's institution, the accumulation of technological knowledge, the collaboration with other institutions or firms, accumulation of technological knowledge and invention scope, and, negatively with the researcher's square age.

The paper is presented in six sections. The second section discusses the relevant theoretical and empirical findings concerning inventors and academic patents. The third section describes the university researchers that are members of the SNI and the patented inventive activity in the United States Patent and Trademark Office (USPTO), in the framework of advanced education and research institutions of Mexico, the National System of Researchers of the National Science $\&$ Technology Council (CONACYT). Section four will develop an empirical study that seeks to validate the research hypothesis about factors affecting propensity of academic researchers to become inventors, specifying sources of data, the econometric models proposes and analyzing the results. Section five will extend the empirical study to test the hypothesis about the factors associated to the productivity of academic inventors. Conclusions will be presented in section six.

\section{Theoretical background}

The growing demand for universities to participate in the generation of patents has aroused an important debate, given that despite the possible benefits; there are also significant potential costs (Jaffe and Lerner, 2007; WIPO, 2011). Although the debate remains open, the data shows increased growth in academic patents in both developed and emerging countries alike. Moreover, both types of countries are undergoing legislative changes in order to favor the patenting of new technological knowledge generated in universities and research institutes, and generally, to foster the transfer of technological breakthroughs to the productive fabric.

Although patents represent just one part of the transfer mechanisms, licensing is a relevant instrument for innovation in specific contexts, such as in the life sciences area (Colyvas $e t$ al., 2002). Despite the limitations of using patents as an indicator, ${ }^{3}$ there are cases where the research is conducted in a university, but the rights are requested by other individuals or legal entities, whether these be the very academic inventors or companies that hold the patents. This idea gives rise to research that suggests the importance of conducting an analysis of university patents using the inventor as the unit of study (Balconi, Breschi and Lissoni, 2004; Breschi, Lissoni and Montobio, 2008 and Carayol, 2007).

\section{Academic inventors}

In this investigation we define academic inventor as a scientist who appears as an inventor on a patent that is held by a university, an institute of advanced education (institución de educación superior, IES for its acronym in Spanish) or public research institution (institución pública de investigación, IPI for its acronym in Spanish) who is also affiliated with this institution. According to Lissoni (2012) and Dornbusch, Schmoch, Schulze and Bethke (2013),

\footnotetext{
${ }^{3}$ Since not all research results are liable to be patented or when the decision not to patent is made for strategic regions.
} 
this concept is used on studies on academic patents, industrial property and governance models in universities and research institutions.

In terms of industrial property laws, university rules and regulations on transfer of technology can provide academic researchers with a strong incentive to look for possible practical applications for their work. ${ }^{4}$ In this sense, another key distinction is the autonomous nature of institutions that implies self-governance regarding rules and regulations, curricular contents, budget usage and management.

From an origin of knowledge perspective, the unit of analysis is the academic inventor who is the origin of the invention in terms of their personal characteristics. Scientists are faced with the choice of problems, and this choice depends on incentives such as material reward, social prestige or intellectual satisfaction. Even though the literature on patents highlights the importance of the analysis of institutional and organizational aspects that foster the generation of patents, it is important to know researchers' motivations for taking part in the inventive activities of institutions.

The increase in studies on the generation of patents have increased using studies on American universities as background (e.g. Azagra-Caro, Carayol 2007; Henderson, Jaffe and Trajtenberg, 1998; Mowery, Sampat and Ziedonis, 2002; Trajtenberg, Henderson and Jaffe, 2002; Mowery and Sampat, 2006) highlight certain elements that influence the transfer of technology, such as the institutional characteristics of universities, the resources set aside for $R \& D$, the rules and regulations on matters of industrial property between university and researchers, support structures like Technology Transfer Offices (тTо) and environmental characteristics. Despite significant evidence, it should be noted that the phenomenon is not homogeneous by country or sector (Henderson, Jaffe and Trajtenberg, 1998; Geuna and Nesta, 2006; Zeebroeck, Van Pottelsberghe and Guellec, 2008).

Henderson, Jaffe and Trajtenberg (1998), who compared university patents with a sample of U.S. industrial patents, carried out one of the precursory works. The authors pointed out three factors to explain the development of university patents: the legal framework, a consequence of the legislative amendments that allowed universities to file patent applications; the increase in private funding to support research, and the growth of intermediary innovation bodies.

University rules and regulations on the transfer of technology can provide academics with a strong incentive to search for industrial applications for their research results. The analysis documents on the Bayh-Dole Act in the United States show that universities that assign personnel a greater proportion of royalty income generate a higher number of patents and licensing revenues. Lach and Shankerman (2008), emphasize that the agreements for the assignment of royalties vary substantially and are related with the characteristics observed in universities, such as the size of the academic staff, quality, financing of research, the technological knowledge of the investigative body and characteristics of the TTO. Likewise in the analyses of European countries (e.g. Baldini, 2006), certain characteristics of universities have a significant influence on the generation of patents that can be even more relevant than the forms of intellectual property regulation.

There are different studies that characterize inventors and analyze how different variables influence their inventive activity. Age is one of the factors that stand out to explain great scientific output or how it is linked to scientific genius (Jones, Reedy and Weinberg, 2014). In addition to

\footnotetext{
${ }^{4}$ Research into the effects of the Bayh-Dole Act in the United States shows that agreements for assigning royalties vary substantially between universities and that universities that allocate personnel a higher portion of income from royalties generate more patents and licensing revenue (Lach and Shankerman, 2008).
} 
this, other investigations include: gender, education, the inventor's motivations for inventing, labor mobility, and education level (Giuri, et al. 2006; Walsh and Nagaoka, 2009). Special emphasis is also placed on the academic networks of individuals, which favor the geographical extension of the spread of knowledge (Fleming and Frenken, 2006; Giuri et al. 2007). Added to the profile, motivations and mobility of inventors is their inventive performance (Walsh and Nagaoka, 2009). The characterization of great inventors also considers formal education, patent registrations, their career in the industry and degree of specialization (Khan). It is also possible to find some studies aimed at analyzing the attitudes and behavior of university academic inventors (Baldini, Grimaldi and Sobrero, 2005).

\section{University researchers and inventive activity patented by universities in Mexico}

This investigation considers the researchers-inventors of the National System of Researchers of the National Science \& Technology Council (CONACYT) ${ }^{5}$ of patents granted to universities or research institutes by the USPTO.

The SNI confers the national researcher honor to those who excel in their research activity in different scientific disciplines. SNI researchers are distributed among institutes of advanced education, public research centers (centros públicos de investigación, CPI), governmental agencies and companies. Public universities have the highest number of researchers; therefore, as of 2014, 71\% of SNI researchers are found in IES. In 1984, the SNI had 1,396 researchers (men: $82 \%$ and women: $18 \%$ ). After almost thirty years, the number of researchers has increased to 19,655 researchers (men: 66\% and women: $34 \%$ ) in 2013, which is an average annual increase of $9.2 \%$ (CONACYT, 2014).

Regarding the distribution of SNI researchers according to academic area, in 2002, of the 7,982 SNI researchers, $20.1 \%$ belonged to the Physics-mathematics area, $17.8 \%$ to the Biology area, $17 \%$ to Humanities and $12.4 \%$ to Engineering. The areas with the highest percentage of SNI researchers were social sciences, Biotechnology and Medicine with 11.5\%, 10.7\%, and $10.5 \%$, respectively. In 2013, the areas of Biology and Medicine remained without significant changes with $17 \%$ and $10.3 \%$, respectively. In comparison, however, the Social Sciences, Biotechnology and Engineering areas increased their participation to $15.2 \%, 11.8 \%$, and $14.8 \%$, respectively.

In 1984, the average age of SNI researchers was 40 years and remained relatively constant until 1992. As of 1993, a slow but sustained increase in average age was observed, remaining relatively constant once more as of 2004. In 2010, the average age of SNI researchers was 49 years. Thus, the average age of SNI researchers has increased by almost a decade over the last 25 years.

The SNI considers patents to be a valuable academic product, and as such, have a positive influence on researcher evaluation. Of the 959 patents granted to Mexican holders by the USPTO between 1980 and 2013, 143 correspond to universities and Mexican institutions, that is, $14.9 \%$, with an average annual increase of $9.5 \%{ }^{6}$

\footnotetext{
${ }^{5}$ The Conacyt is a decentralized public body of the Federal Public Administration created in 1979 to implement policies and programs to promote scientific research and academic enrichment. Its objective is to consolidate a science and technology system that responds to the country's priority demands, provides a solution to the specific problems and needs, and contributes to elevate the population's well-being and quality of life. Conacyt prioritizes its efforts to support universities and public research centers, and the academics affiliated with them (OMPI, 2000).

${ }^{6}$ Nevertheless, the low level of patents granted to Mexico, if compared with industrialized countries and even emerging Asian countries, between 1980 and 2013, the patents granted registered average annual growth of $8 \%$.
} 
At least one SNI researcher was involved in ninety-one of the one hundred forty-three patents (63.64\%) in the areas of 1) Physics-mathematics and Earth Sciences; 2) Biology and Chemistry; 3) Medicine and Health Sciences; 6) Biotechnology and Agricultural Sciences; and 7) Engineering ${ }^{7}$. No SNI researcher from any of the same areas took part in the remaining fiftytwo patents (36.36\%). When the classification is performed according to university and institute, we find that the involvement of at least one SNI researcher in patents granted by the USPTO was: 20 of 25 granted to the Mexican Petroleum Institute (Instituto Mexicano del Petróleo, -IMP-), 17 of 22 granted to the Autonomous University of Mexico (Universidad Nacional Autónoma de México, -UNAM-); 17 of 19 granted to the Center for Research and Advanced Studies (Centro de Investigación y de Estudios Avanzados, -CINVESTAV-), whereas 12 of the sNI researchers patented in a different university or institute to the one they were affiliated with in 2013.

In terms of the size of the research team, $2.2 \%$ of the 91 patents that involved SNI researchers, the patented invention was developed individually, $72.5 \%$ of the patents were the result of a team of 2 to 5 researchers/inventors and in $25.3 \%$ of the patents, the research team was made up of more than 5 researchers.

At least one SNI researcher took part in 32 of the 48 patents corresponding to Chemistry; in 31 of the 47 patents for Medications and medicine; and in 13 of 24 patents granted in Mechanics.

\section{Inventors as members of the National System of Researchers}

From the 143 patents granted by the USPTO to universities and institutes in Mexico, $75 \%$ correspond to universities and $25 \%$ to research institutes. A total of 332 inventors were identified in this collection of 143 patents. ${ }^{8}$ The analysis of the individual characteristics of inventors has been supplemented with the database on active researchers in the SNI during 2013. Information was used on researchers registered in the areas that were considered highly likely to patent: 1) Physics-mathematics and Earth Sciences; 2) Biology and Chemistry; 3) Medicine and Health Sciences; 6) Biotechnology and Agricultural Sciences; and 7) Engineering. Cross-referencing the names of inventors of the USPTO with researchers of the CONACYT revealed coincidences in 113 cases. These researchers form part of the core of our research as they have at least one patent in the USPTO. Below we look at some of the characteristics related to this group of researchers.

Of the 113 inventors who are SNI researchers, 27\% belong to Level I (30 researchers), 36\% to Level II (41 researchers), 36\% to Level III (41 researchers) and 1\% is classified as Candidate (1 researcher). Of the 113 researchers, 97\% hold a Doctorate (110 researchers) and only 3\% (3 researchers) have a Master's Degree.

As regards to gender, male researchers predominate (90 researchers) over female researchers (23 researchers); in other words, $80 \%$ are men and $20 \%$ are women.

\footnotetext{
${ }^{7}$ The analysis of the participation of SNI researchers in the 143 patents granted by the USPTO to Mexican universities and institutes is performed for researchers who belong to areas 1, 2, 3,6 and 7.

${ }^{8}$ Five universities and institutes stand out for having the highest number of patents granted by the USPTO. In first place is the Mexican Petroleum Institute with 25 patents. This is followed by the UNAM with 22 patents. Next is the Center for Research and Advanced Studies (Centro de Investigación y de Estudios Avanzados) of the National Polytechnic Institute (Instituto Politécnico Nacional) (CIENVESTAV for its acronym in Spanish) with 19 patents granted. Then there is the Mexican Institute for Metallurgy Research (Instituto Mexicano de Investigaciones Siderúrgicas, IMIS for its acronym in Spanish) with 11 patents. Lastly, the Centro de Investigación and Asistencia Técnica del Estado de Querétaro, A.C. (Center for Research and Technical Assistance of the State of Querétaro, CIATEQ for its acronym in Spanish) with 8 patents.
} 
Regarding the state of the Republic where researchers have their affiliation, half of the researchers are in some university or institution located in Mexico City (57 researchers), 13\% in Morelos (15 researchers), 9\% in Nuevo León (10 researchers) and 28\% in 10 other states of the Republic 9 .

Concerning the seniority in the SNI, it is worth noting that $19 \%$ of researchers have 26 years of seniority in the SNI. The seniority of the remaining researchers is highly diverse and follows no clear pattern. The average seniority of the 113 SNI researchers-inventors affiliated with universities or institutes is 18 years.

As for the classification of researchers by area of investigation, 45 researchers belong to the Engineering area (40\%), 30 researchers to Biology (27\%), 16 researchers to Biotechnology (14\%), 13 researchers to Physics-mathematics (12\%), and 9 researchers to the area of Medicine and Health Sciences (8\%).

According to the academic field of study, $40 \%$ (46 researchers) belong to the field of Technological Sciences, 25\% (28 researchers) to the field of Life Sciences, 11\% (13 researchers) to the field of Physics, and 10\% (11 researchers) to the field of Chemistry. The remaining researchers belong to the fields of Medicine and Human Pathology (6\%, 7 researchers), Agricultural and Veterinary Sciences (5\%, 6 researchers), Health Sciences (1\%, 1 researcher), and finally Earth and Cosmic Sciences (1\%, 1 researcher).

The average age of the 113 researchers is 56 years. Furthermore, the average age of SNI researchers is 45 years. The inventors who apply for the most patents are between the ages of 42 and 49 years.

As regards to the distribution of the number of patents in the USPTO where an SNI researcher appears, 74 of the 113 researchers have only one patent in the USPTO. In other sectors, 16 researchers have only two patents, and 9 researchers have three patents. Worth noting is the fact that 2 researchers have 7 patents and 1 researcher has 8 patents granted by usPTO. The average number of patents per researcher is 2 patents.

In respect to the institution of affiliation, three institutions concentrate the highest percentages of the researchers. A little more than a quarter (29 researchers) are affiliated with the Mexican Petroleum Institute (IMP); almost another quarter part (27 researchers) to the UNAM, and 14\% (16 researchers) to the Center for Research and Advanced Studies of the Polytechnic Institute (CINVESTAV). The remaining researchers (36\%) are affiliated with the different institutions which range from the Instituto Potosino de Investigación Científica y Tecnológica A.C. (Potosine Institute for Scientific and Technological Research) to the Ministry of Health.

Concerning the SNI researchers by institution: the UNAM stands out with 2,680, the CINVESTAV with 687, and the Autonomous Metropolitan University (Universidad Autónoma Metropolitana) with.

The variable propensity for researchers to be inventors in a university or research institute patent is estimated through the probability of academics being inventors in academic patents, as a proxy variable..$^{10}$ This probability is expressed as:

$\mathrm{P}(\mathrm{A})=$ the number of events $\mathrm{A} /$ the number of events $\Omega$

Where:

$\mathrm{A}=$ the number of SNI inventors-researchers from areas 1, 2, 3, 4 and 7 in 2013 that are also inventors in patents of Mexican institutions granted by the uSPTO during the period 1980-2013 and

$\Omega=$ the total number of SNI researchers in 2013 of each institution. This probability can be expressed in values between $[0,1]$ or $[0 \%, 100 \%]$.

\footnotetext{
${ }^{9}$ The order by number or researchers: San Luis Potosí (6), Baja California (4), Querétaro (5), Guanajuato (4), Chihuahua (3), Coahuila (2), State of Mexico (2), Sonora (2), Veracruz (2) and Yucatán (1).

${ }^{10}$ Rincón and Correa, 2007; Sánchez, E. A. S., Cazares, S. I., and Antuna, 2015.
} 
The IMP stands out with a propensity to patent of 0.1706 , that is, $17 \%$ of SNI researchers of this Institute have patented in the USPTO. The Instituto Potosino de Investigación Científica and Tecnológica A.C. and the Monterrey Institute of Technology and Advanced Studies (Instituto Tecnológico and de Estudios Superiores de Monterrey) stand out with a propensity to patent of $7 \%$ and $5 \%$, respectively. The cases of the UNAM and CINVESTAV are also worth mentioning as both institutions stand out in terms of the absolute number of their SNI researchers who were registered as inventors with the USPTO in 2013; their propensity to patent are relatively low with values of $1 \%$ and $2 \%$, respectively.

In order to test the first hypothesis of this investigation which states that the probability of SNI researchers to participate in inventions patented by their institutions is small, we used information on the total number of active researchers in the SNI in the areas considered likely to patent (areas 1, 2, 3, 6,7), which gives a total sum of 14,821 researchers. We also used the information of the 113 inventors and SNI researchers that were identified in patents granted to Mexican universities and institutes. The probability of finding an SNI researcher among the inventors of a patent granted by the USPTO to a Mexican university or institute is $0.76 \%$. The propensity of the Mexican Petroleum Institute, however, is 17\%; the CINVESTAV 2\% and the UNAM $1 \%$ (see table 1$)$.

Table 1.

Propensity of researchers to become inventors at universities or research centers

\begin{tabular}{|c|c|c|c|c|}
\hline $\begin{array}{l}\text { University or Research Institutes which have patents granted by } \\
\text { USPTO, 1980-2013 }\end{array}$ & $\begin{array}{l}\text { SNI researchers } \\
\text { inventors (a) }\end{array}$ & $\%$ & $\begin{array}{l}\text { Total of SNI } \\
\text { researchers at } \\
\text { the institución } \\
\text { (b) }\end{array}$ & $\begin{array}{c}\text { Propensity of } \\
\text { researchers to } \\
\text { become inventors } \\
\text { in each } \\
\text { institution (c) } \\
\end{array}$ \\
\hline Instituto Mexicano del Petroléo & 29 & 25 & 170 & 0.1706 \\
\hline Universidad Nacional Autónoma de México & 27 & 24 & 2680 & 0.0101 \\
\hline Centro de Investigación y de estudios avanzados del IPN & 16 & 14 & 687 & 0.0233 \\
\hline Instituto Tecnológico y de Estudios Superiores de Monterrey & 8 & 7 & 141 & 0.0567 \\
\hline Instituto Potosino de Investigación Cientifica y Tecnológica AC & 5 & 4 & 68 & 0.0735 \\
\hline Universidad Autỏnoma Metropolitana & 4 & 4 & 557 & 0.0072 \\
\hline Universidad de Guanajuato & 4 & 4 & 244 & 0.0164 \\
\hline Centro de Investigación Cientifica y de Educación Superior de Ensenada & 3 & 3 & 167 & 0.0180 \\
\hline Centro de Investigación en Materiales Avanzados SC & 3 & 3 & 68 & 0.0441 \\
\hline Centro de Investigación en Alimentación y Desarrollo AC & 2 & 2 & 112 & 0.0179 \\
\hline Instituto Nacional de Investigaciones Nucleares & 2 & 2 & 77 & 0.0260 \\
\hline Instituto Nacional de Neurologia y Neurocirugia & 2 & 2 & 89 & 0.0225 \\
\hline Universidad Autónoma de Nuevo León & 2 & 2 & 445 & 0.0045 \\
\hline Instituto de Ecologia $A C$ & 1 & 1 & 103 & 0.0097 \\
\hline Instituto Nacional de Psiquiatria & 1 & 1 & 52 & 0.0192 \\
\hline Universidad Autónoma de San Luis Potosí & 1 & 1 & 315 & 0.0032 \\
\hline Universidad Autónoma de Yucatản & 1 & 1 & 144 & 0.0069 \\
\hline Universidad Veracruzana & 1 & 1 & 217 & 0.0046 \\
\hline Secretaria de Salud & 1 & 1 & 94 & 0.0106 \\
\hline
\end{tabular}

Source: own estimation based in USPTO and Conacyt data. 


\section{Which factors explain the propensity of academic researchers to become inventors of university patents?}

Once confirmed that the Mexican SNI academic researchers propensity of being inventors of novelties patented by their institutions is still low, we follow to test our hypothesis set out in the sense that this propensity grows when they belong to institutions with an intellectual property regulation and also it is associated with: the researcher's age and its SNI level, as personal factors; the institution size and the number of $\mathrm{PhD}$ programs approved by CONACYT quality control, as institutional factors; finally, the importance of the invention, the novelty activity and the technological amplitude, as factors of the research nature.

In order to analyze which factors are contributing to the propensity of academic researchers to become inventors of institutional patents we propose two econometric models taking into account Schumpeterian framework and the previous empirical studies contributions. The first one is considering the personal and institutional factors; the second one is build with the USPTO patents micro-data granted to Mexican institutions to find out how innovation nature elements are affecting this propensity.

\section{Methodology}

\section{First econometric model}

In order to analyze which individual and institutional factors have influence into the propensity of academic researcher to become inventors we propose a least mean squares $(L M S)$ model, taking into account variables tested by other studies and also with new variables.

\section{Data sources}

Our research is focused on the individual and institutional of 113 sNI's researchers from areas 1, 2, 3, 4 and 7 in 2013, identified as inventors in the universe of usPTO patents granted to Mexican universities during 1980-2013.

The full model is expressed as follows:

$$
\text { pip }=\beta_{0}+\beta_{1} x_{1}+\beta_{2} x_{2}+\varepsilon
$$

We set up a linear model relating the terms in the full model to a function of explanatory variables.

Where:

pip $=$ propensity or probability of SNI's academic researchers to become inventors in patents of their universities or research institutions. It is the dependent variable.

$\beta_{0}=$ constant;

$x_{1}=$ individual researchers-inventors factors;

$x_{2}=$ institutional factors, and

$u=$ mean square error

The dependent variable (pip). The variable propensity for Mexican SNI's researchers to become inventors in patents which owns to an university or a research institute (pip) is 
estimated through the probability of academics of being inventors in academic patents, as a proxy variable ${ }^{11}$. We found out likelihood from 0.0070 as minimum and 0.0559 as maximum.

Table 2 .

Dependent variable: Propensity of academic researchers to become inventors of universities and research institutions' patents

\begin{tabular}{c|c}
\hline Variable & Coefficient Specification \\
\hline pip (A/B) & $\begin{array}{c}\text { Number of SNI researchers-inventors of universities and research } \\
\text { institutes patents (A) }\end{array}$ \\
\cline { 2 - 2 } & \begin{tabular}{c} 
Total of patents where the holder is university or research institute (B) \\
\hline
\end{tabular} \\
\hline
\end{tabular}

Source: own estimation.

Independent variables. $x_{1}=$ individual researchers-inventors factors

The independent variables used in order to measure the influence of individual factors are:

i) sni_2013: the researcher's productivity, where the SNI level of academic researchers is the proxy variable. As a researcher achieves more scientific articles or/and books published, $\mathrm{PhD}$ graduates directed, patents or design models, among other outcomes, he increases his productivity and therefore he could obtain in ascendant a SNI level. (Huber, 2001; Rodeiro, Fernández, Rodríguez y Otero, 2012; Aceytuno y Sánchez, 2014; Calderón, 2013). The distribution of SNI researchers level is relatively similar: $27 \%$ SNI level 1; 36\% SNI level 2 and, $36 \%$ sNI level 3 (Conacyt, 2013).

ii) age_average: the age average of the researchers-inventors linked to the probability to become an inventor (Giuri, et al. 2006; Walsh and Nagaoka, 2009 and Jones, Reedy and Weinberg, 2014). ${ }^{12}$

iii) Square age: the age linked to the productivity factors. The researcher-inventor age square is the proxy variable. We suppose that the productivity of younger researchers is decreasing and positive and in the researcher more aged, the productive is also decreasing but negative (Aceytuno y Sánchez, 2014), and

iv) res_team_mixed: the research team mixed of women and men researchers-inventors has the possibility of interact the different capabilities according to gender (Morales y Sifontes, 2011; Aceytuno y Sánchez, 2014).

\footnotetext{
${ }^{11}$ This dependent variable of the model has been estimated as a proxy variable by taking into account the classical likelihood: the number of favorable outcomes of an event divided by the total number of possible outcomes.

${ }^{12}$ The number of observations are 111 because we have not dispose of the age of two researchers.
} 
Table 3.

Individual factors variables

\begin{tabular}{|c|c|c|c|}
\hline \multicolumn{4}{|c|}{ Independent variables: $\mathrm{X} 1$ Individual factors } \\
\hline & Description & Specification & Hypothesis \\
\hline sni_2013 & $\begin{array}{l}\text { Productivity of the academic } \\
\text { researcher. The proxy variable is the } \\
\text { Mexican SNI academic researcher- } \\
\text { inventor in 2013. Numerical variable. }\end{array}$ & $\begin{array}{l}1=\text { Candidate; } \\
2=\text { SNI I; } \\
3=\text { SNI II and } \\
4=\text { SNI III }\end{array}$ & $\begin{array}{l}\text { As higher SNI researcher level, } \\
\text { as bigger will be the pip. }\end{array}$ \\
\hline age_average & $\begin{array}{l}\text { Age average of SNI researcher- } \\
\text { inventors in the year of the patent } \\
\text { application. Numerical variable }\end{array}$ & $28-76$ & $\begin{array}{l}\text { As middle age of the } \\
\text { researchers-inventors than } \\
\text { younger or older age as more } \\
\text { influence will have on the pip. }\end{array}$ \\
\hline square age & $\begin{array}{l}\text { Age linked to academic researcher } \\
\text { productivity. The proxy variable is } \\
\text { the researcher-inventor age square. } \\
\text { Numerical variable. }\end{array}$ & $784-5,776$ & $\begin{array}{l}\text { The researcher-inventor age } \\
\text { square will affect negatively } \\
\text { on the pip. }\end{array}$ \\
\hline res_team_mixed & $\begin{array}{l}\text { Research team mixed of women } \\
\text { and men. Point out if in the research } \\
\text { team there are collaboration of men } \\
\text { and women researchers-inventors. } \\
\text { Dummy variable. }\end{array}$ & $\begin{array}{l}1=\text { Men and } \\
\text { women } \\
0=\text { only men or } \\
\text { only women }\end{array}$ & $\begin{array}{l}\text { As the research team will be } \\
\text { mixed of men and women } \\
\text { researchers-inventors as higher } \\
\text { will be the pip. }\end{array}$ \\
\hline
\end{tabular}

Independent variables. $x_{2}=$ institutional factors

The independent variables used in order to measure the influence of institutional factors are:

i) prop_pat_U\&RI: the university and research institutes propensity to patent where each researcher-inventor works. This numerical variable suggests the capabilities of each university to patent associated to the institutional incentives to foster the inventive potential among their researchers, including the IP strength regulation. The scale of this propensity goes from 0.0032 to 0.1706 that shows the important heterogeneity among the universities.

ii) $t$ to: technology transfer office indicates if the university or research institutes has this kind of office which allow for commercializing patents through licenses or for having a joint agreement with firms to develop a new product or process (Rodeiro, Fernández, Rodríguez y Otero, 2012). It is a dummy variable;

iii) PhD prog_pnpc: number of $\mathrm{PhD}$ programs of each institutions in the $1,2,3,4$, and 7 areas recognized by Conacyt by their academic quality recognized by the Padrón Nacional de Posgrados de Calidad de Conacyt -PNCP- (Quality Mexican Group of PhD). It suggest the potential of $\mathrm{PhD}$ to develop academic research an new scientific and technological knowledge and therefore increase de pip (Calderón y García-Quevedo 2012; Calderón, 2013), and

iv) inst_size: size of the institute measured by the total number of SNI researchers in each university or research institution. It suggests that research capabilities and quality level to be develop by these researchers. Numerical variable. (Rodeiro, Fernández, Rodríguez y Otero, 2012; Calderón y García-Quevedo, 2012; Calderón, 2013). 
Table 4

Institutional factors variables

\begin{tabular}{|c|c|c|c|}
\hline Variable & Description & Scale/Rank & Hiphotesis \\
\hline prop_pat_Ud\&Rd & $\begin{array}{l}\text { University and research institutes } \\
\text { propensity to patent where each } \\
\text { researcher-inventor works. } \\
\text { Numerical variable* }\end{array}$ & $0.0032-0.1706$ & $\begin{array}{l}\text { As higher is the propensity to } \\
\text { patent of the universities and } \\
\text { research institutes as bigger will } \\
\text { be the pip. }\end{array}$ \\
\hline tto & $\begin{array}{l}\text { Technology transfer office. } \\
\text { Indicates if the institution has set } \\
\text { up the IP and TT regulation and, } \\
\text { therefore how there are incentives } \\
\text { to create new technological } \\
\text { knowledge. Dummy variable }\end{array}$ & $\begin{array}{l}1=\text { has TTO; } \\
2=\text { doesn't have } \\
\text { TTO }\end{array}$ & $\begin{array}{l}\text { As more universities and } \\
\text { research institutes have TTO } \\
\text { and more IP strength regulation } \\
\text { as higher will be the pip. }\end{array}$ \\
\hline $\begin{array}{l}\text { PhD } \\
\text { prog pnpc }\end{array}$ & $\begin{array}{l}\text { Number of PhD programs of each } \\
\text { institutions in the } 1,2,3,4 \text {, and } 7 \\
\text { areas recognized by Conacyt by } \\
\text { their academic quality (PNCP**). } \\
\text { Numerical variable. }\end{array}$ & $0-29$ & $\begin{array}{l}\text { As more number of PhD } \\
\text { belonging to PNCP of Conacyt, } \\
\text { as bigger will the pip. }\end{array}$ \\
\hline inst_size & $\begin{array}{l}\text { Size of the institution measured by } \\
\text { the total number of SNI } \\
\text { researchers*** in each university } \\
\text { or research institution. Numerical } \\
\text { variable. }\end{array}$ & $52-2,680$ & $\begin{array}{l}\text { As bigger is the number of SNI } \\
\text { researehers as higher will be the } \\
\text { pip. }\end{array}$ \\
\hline
\end{tabular}

* Souce: own estimation based on SNI researchers from Conacyt and USPTO patents granted to U\&RI.

*PNPC = Padrón Nacional de Posgrados de Calidad de Conacyt (Group of Mexican of PhD Recognized by of National Council of S\&T).

** SNI researchers of Conacyt data 2013.

By considering the previous explanation, the specification of the model is expressed as follows:

$$
\begin{aligned}
& \text { pip } \\
& =\beta_{0}+\beta_{1} s n i_{2013}+\beta_{2} \text { age }+\beta_{3} \text { age_productivity }+\beta_{4} \text { res_team_mixed } \\
& +\beta_{5} \text { tto }+\beta_{6}+\beta_{7 P h D \_} \text {prog_pnpc }+\beta_{8} \text { inst_size }+u
\end{aligned}
$$

\section{Outcomes}

The findings of our estimations confirm partially the hypothesis in the sense that individual and institutional factors proposed have a positive influence on the pip. Every independent individual variable has a significant impact: the researcher's productivity (SNI_2013), as its coefficient 0.003 shows; the age average of the researchers-inventors linked to the probability to become an inventor (age_average); the age linked to the productivity factors (square_age), except research team mixed of women and men (res_team_mixed), which has not.

Concerning SNI_2013, it seems we confirm what others authors have found about that the researcher productivity increases as he participates as inventors of university's patents (Rodeiro, Fernández, Rodríguez y Otero, 2012; Calderón, 2013). 
As we expected, the coefficient of age_average has a positive effect and that one of the square age has a negative influence on the dependent variable. In that sense, we confirm that on the middle age of the researchers-inventors will have more propensity to become inventor than in younger or older age, although the middle age can differ according the diverse studies. We found that at 50.11 years old of the SNI researcher-inventor is the age more creative. This result coincides with Aceytuno y Sánchez (2014) and Jones, Reddy and Weinberg (2014) and which study the age and scientific genius, but it differs with others by considering some arguments. Adams (1946) finds that “... the peak age varies between 37 and 47 years old, depending on the scientific discipline, and argues that disciplines that emphasize mathematical deductive reasoning tend to display younger peak ages of great achievement (cited in Jones, Reddy and Weinberg, 2014: 13). Analyzing the Nobel laureates in Economics, Weinberg and Galenson (2005) identify that "the most conceptual laureate did his most important work at 32.5 years of age compared to 53.2 for the most experimental, a difference of 20.7 years (cited in Jones, Reddy and Weinberg, 2014: 22). Perhaps this could be compared with the scientific researchers and technological researchers. The studies about the age of scientific researchers and their productivity also confirm the same tendency. Older the researcher will be his creativity will be diminishing.

As the outcomes shows, the research team mixt variable has not a statistical significance. It could be probably associated to the fact that most part of the research teams are integrated jointly by women and men and therefore, there is a complementarity capabilities in the research teams (Morales and Sifontes, 2011). We have tested alternatively the gender variable in a separate model from the research team because they are both highly correlated. The gender variable appears with less significance than research team mixt and it detracts prediction to the model.

With respect to the institutional variables considered, we have found that prop_pat_U\&RI, PhD_prog_pnpc and inst_size affect positively to the propensity of SNI researchers to become inventors, while the variable, technology transfer office (tto) has not influence in the pip.

Concerning the university and research institutes propensity to patent where each researcherinventor works ( $p r o p \_p a t \_U \& R I$ ), its coefficient is 0.063 . This variable accounts for recognizing the involvement of researchers in the technological knowledge development process in the universities or research institutions. Specially, it becomes crucial to take advantage of the knowledge potentiality of SNI researchers to develop new technological process or products, which would have an impact in the productivity and economic performance.

The number of $\mathrm{PhD}$ programs of each institution in five scientific areas recognized by Conacyt by their academic quality (PhD_prog_pnpc) affect positively on the pip and it is significant at $95 \%$. Nevertheless the small effect, the PhD prog_pncp variable is a right indicator of the institution capabilities to develop research and invention activities.

In turn, the coefficient of the size_inst variable, in terms of number of SNI researches in each university or research, implies that higher is the SNI researchers in the institution will be a positive propensity of the researcher to become inventor. Therefore, the size of the institution seems to have a positive effect on the pip. Accounting the database of this research, we identify research teams clearly defined. Basically, SNI researchers integrate the research teams; many of them are participating more than one time. To foster the incorporation of more researchers to the SNI in each institution could create more researchers teams involved in the inventive activity. The inst_size variable is significant at $90 \%$. 
In opposite, the variable, technology transfer office (tto) has not a positive influence in the pip. Probably, it could be explained by the absence of technological transfer office in various institutions. As we have seen in the theoretical background, the presence of this kind of institution could incentivize the propensity of researchers to become inventors, as their inventions patented could be transfer or licensed to the industrial sector.

Table 5 .

Outcomes of individual and institutional factors affecting propensity of academic researchers to become inventors model

\begin{tabular}{|c|c|c|c|c|c|c|c|c|}
\hline & Mean & Std. Dev. & Min. & Max. & Coefficient & $\begin{array}{c}\text { Robust } \\
\text { standard } \\
\text { errors }\end{array}$ & $t$ & p value \\
\hline \multirow{2}{*}{$\begin{array}{l}\text { pip } \\
\text { sni_2013 }\end{array}$} & 0.01 & 0.01 & 0,01 & 0.06 & & & & \\
\hline & 3.08 & 0.81 & 1 & 4 & $0.0036096 *$ & 0.0012 & 3.13 & 0.002 \\
\hline age_average & 45.59 & 8.05 & 28 & 76 & $0.0015835 *$ & 0.0006 & 2.83 & 0.006 \\
\hline square age & $2,133,60$ & 795.82 & 784 & 5,776 & $-0.0000158 *$ & 0.0000 & -2.99 & 0.004 \\
\hline $\begin{array}{l}\text { res_leam } \\
\text { mixed }\end{array}$ & 0.68 & 0.47 & 0 & 1 & -0.0026617 & 0.0018 & -1.49 & 0.14 \\
\hline prop_pat_U\&RI & 0.06 & 0.07 & 0.00 & 0.17 & $0.0634094 *$ & 0.0194 & 3.27 & 0.001 \\
\hline tto & 0.58 & 0.50 & 0 & 1 & -0.0020475 & 0.0016 & -1.25 & 0.213 \\
\hline PhD prog_pnpc & 12.15 & 11.62 & 0 & 29 & $0.0003983 *$ & 0.0002 & 2.49 & 0.014 \\
\hline inst_size & $1,157.50$ & $1,508.56$ & 61 & 3,805 & $-0.0000015^{*}$ & 0.0000 & -1.73 & 0.086 \\
\hline \multicolumn{6}{|l|}{$R 2=0.2521$} & \multicolumn{3}{|c|}{$F=0.0138$} \\
\hline \multicolumn{9}{|l|}{$N-111$} \\
\hline "-Significaticant at 10 & & & & & & & & \\
\hline Significani $p<0.01$ & & & & & & & & \\
\hline
\end{tabular}

Second econometric model: factors of nature of innovation

As we have seen above, we propose a second model with the micro-data base of the USPTO patents granted to Mexican universities and research institutions in order to test the hypothesis in the sense that the size of the inventor team, the accumulation of technological knowledge, the academia-industry links, the importance of the invention, number of novelties generated, technological scope and technological collaboration with other institutions or firms, as the factors which characterize the inventive activity, could have an impact on the propensity of researchers to become inventors. We take in account the various studies made using the micro data of the patents.

The model is expressed in the following equation:

$$
p i p=\beta_{0}+\beta_{3} x_{3}+\varepsilon
$$


Where:

pip $=$ propensity of SNI researcher to become inventor of university or institution patents

$\beta_{0}=$ Constant

$x_{3}=$ Ensemble of nature inventive factors

$\varepsilon=$ Error term.

The independent variables $x_{3}$ of the nature of invention factors are:

i) tech_scope $=$ Technological scope, measured by the number technological classes where the patent is involved (Trajtenberg and Jaffe, 2002; Maldonado, Guzmán y Peredo, 2015).

ii) tech_collab $=$ Technological collaboration. We use as a proxy variable the co-patent. It is a dummy variable, 1 when the co-patent is property of two or more institutions or 0 when the patent is there is not co-patent. (Urraca, 2005; Guzmán, Acatitla y Vázquez, 2016).

iii) claims = Invention scope. We use as variable the number of novelties in the patent generated and recognized as claims. This numerical variable is associated to: the diffusion of national practices; the complexity of research activities; the emergence of new sectors, and the patent strategies (Guellec, van Pottelsberghe and van Zeebroeck, 2007).

iv) ForwPatCit = Importance of the patent. We use as a proxy variable the forward patent citation (FwPatCit), that is, the number of citation received by the patent (Nuñez and Pedroza, 2011; Morales y Sifontes, 2011; Guzmán, Acatitla y Maldonado, 2015).

By considering the previous explanation, the specification of the model is expressed as follows:

$$
\text { pip }=\beta_{0}+\beta_{9} \text { tech_scope }+\beta_{10} \text { tech_collab }+\beta_{11} \text { claims }+\beta_{12} \text { for } w_{\text {patcit }}+u
$$

In order to prevent the heteroscedasticity, we estimated with standard errors.

Table 6.

The invention nature factors

\begin{tabular}{l|l|l|l}
\hline & Description & Rank & Hyphotesis.. It is expected: \\
\hline \hline tech_seope & $\begin{array}{l}\text { Technological scope, measured by the number } \\
\text { technological elasses where the patent is involved. }\end{array}$ & $01-13$ & $\begin{array}{l}\text { As higher the number the technological } \\
\text { classes involved, the PIP could be } \\
\text { bigger. }\end{array}$ \\
\hline tech_collab & $\begin{array}{l}\text { Technological collaboration. We use as a proxy } \\
\text { variable the co-patent. That is, when the patent is } \\
\text { of the ownership of two or more agents.It is a } \\
\text { dummy variable. }\end{array}$ & $\begin{array}{l}1=\text { co-patent } \\
0=\text { without } \\
\text { catent }\end{array}$ & $\begin{array}{l}\text { As the technological collaboration will } \\
\text { increase, under the co-patent strategie, } \\
\text { the PIP would be higher } .\end{array}$ \\
\hline claims & $\begin{array}{l}\text { number of novelties in the patent generated and } \\
\text { recognized as claims. }\end{array}$ & $\begin{array}{l}2-214 \\
\text { FwPatcit } \\
\text { that is, the number of citation received by the } \\
\text { patent. }\end{array}$ & $\begin{array}{l}\text { As higher would be the number of } \\
\text { patents, the PIP could increase. }\end{array}$ \\
\hline
\end{tabular}

Outcomes

The outcomes confirm positively the hypothesis we set out. Every independent variable considered in this model is statistical significant at $95 \%$. Therefore, the factors identified as 
the nature of invention developed by the SNI researchers in each patent granted to Mexican universities or research institutes: the technological amplitude (tech_scope), the technological collaboration (tech_collab), the invention scope (claims) and, importance of the patent (ForwPatCit) have a positive influence on the propensity of the SNI researchers to become inventors of patents of their universities or institutes (pip).

The technological amplitude has been analyzed as generally index (IGT) (Trajtenberg, Jaffe and Henderson, 1997) to confirm the spreading of nanotechnologies in various technological fields. ${ }^{13}$ It suggests the researcher teams of different scientific fields could foster the pip.

Also the technological collaboration seems to affect positively (coefficient 0.00228 ). As the researcher have research projects with other institutions or universities or firms, the propensity to become inventors in joint patent increases.

In turn, the variable invention scope (claims) which coefficient is 0.00012 affects positively the pip. Taking into account that more claims are associated to the adoption of intellectual property culture, the complexity of research activities, the emergence of new sectors (Guellec, van Pottelsberghe and van Zeebroeck, 2007), among other reasons, when the university or institution is involved in an innovation environment, the academic researchers could be stimulated to be part of the inventive activities.

Finally, forw_pat is a variable that indicates the importance of the patent by the number of citations received by for subsequent patents.

In this second model the R2 is: 0.92 ; so, it seems able to explain how the dependent variable $(P I P)$ could change when there is a marginal increase of the independent variables, by the fact all of them are statistical significant.

Table 7.

Outcomes of the Model of invention nature factors affecting the propensity of academic researchers to become inventors.

\begin{tabular}{|c|c|c|c|c|c|c|c|c|}
\hline Variables & Mean & Std. Dev: & Min & $\operatorname{Max}$ & Coefficient & $\begin{array}{c}\text { Robust } \\
\text { standard } \\
\text { errors } \\
\end{array}$ & $t$ & $p$ value \\
\hline tech_scope & 3.17 & 2.44 & I & 13 & $0.001918^{\circ}$ & 0.00027 & 7,22000 & 0.00000 \\
\hline tech_collab & 0.12 & 0.32 & 0 & 1 & $0.002289^{*}$ & 0.00104 & 2.20000 & 0.03000 \\
\hline claims & 29.04 & 30.28 & 2 & 214 & $0.000112^{*}$ & 0.00002 & 6.21000 & 0.00000 \\
\hline forwPatCit & 7.71 & 18.05 & 0 & 100 & $0.000184^{*}$ & 0.00002 & 9.67000 & 0.00000 \\
\hline Constamt & & & & & $0.001501^{\circ}$ & 0.00039 & 3.87000 & 0.00000 \\
\hline \multicolumn{9}{|c|}{$\mathrm{R}^{2}=0.9275$} \\
\hline \multicolumn{9}{|c|}{$\mathrm{F}=0.0$} \\
\hline & & & & \multicolumn{5}{|c|}{$\mathrm{N}=113$} \\
\hline & & & & \multicolumn{5}{|c|}{ *Significant at $5 \%$} \\
\hline
\end{tabular}

Source: Own estimation.

${ }^{13} I G T=1-\sum_{j}^{n_{1}} S_{i j}^{2}$. where express the percent of forward citation make to patent $i$ belonging to class $j$, among the group $\mathrm{n} 1$ of patent classes. When IGT is equal o near to 1 , it means that the patent $i$ has a wide impact in other technological sectors. In the opposite, when $I G T$ is near to 0 means that patent $i$ has not a wide impact in other technological sectors. 


\section{Factors affecting the productivity of the academic inventor}

Once we have tested our hypothesis about the individual, institutional and the invention nature factors that have influence on the propensity of SNI academic researcher to become inventors in patents of their institutions, we proceed to ask for which factors would affect the productivity of the SNI academic researchers. To that effect, we propose a third econometric model.

Third econometric model: the productivity of the academic inventors

We aim to test the following hypothesis: the productivity of the SNI researchers inventors, specified as two probabilities, is positively associated to the age, SNI level, scientific research field, number of $\mathrm{PhD}$ programs of each institution, invention scope and technological collaboration; and negatively associated to the square age.

This model takes into account the micro database of USPTO patents granted to Mexican universities and institutes and the individual and institutional data of the inventors, which also are SNI researchers.

We propose a logit model, where we look for finding the relation between the productivity of the SNI academic inventors, dependent variable and some individual, institutional and nature invention factor as independent variables. ${ }^{14}$

The logit model is specified in the following equation:

$$
\begin{gathered}
\text { pat }_{\text {logit }}=B_{0}+B_{1} \text { age }+B_{2} \text { square_age }+B_{3} \text { sni }_{2013}+B_{4} \text { scien_resear_area }+B_{5} P h D_{-} p n p c \\
+B_{6} \text { claims }+B_{7} \text { tech_collab }
\end{gathered}
$$

Where:

pat $_{\text {logit }}=$ dependent binary variable. This is a characteristic of the logit models, allowing the classification of the dependent variable in two categories in order to compare the probabilities in two groups. This variable binary which is expressed as:

$0=$ when the SNI researchers have participated as inventors in one patent and

$1=$ when the SNI researchers have participated as inventors in two or more patents.

$\beta_{0}$ to $\beta_{6}$ to $=$ constant;

The independent variables are selected from the individual, institutional and of the nature of productivity that could favor the inventive productivity or the SNI researchers of universities and research institutions, The independent variables are specified like in the previous models, with the exception of scient_resear_area.

Where:

i. age $=$ the age average of the researchers-inventors linked to the date when the patents were granted.

ii. square age $=$ the researcher-inventor age square.

iii. $s n i_{2013}=$ SNI level of academic researchers in 2013.

iv. scient_resear_area $=$ the scientific research area, where the SNI researcher has been classified by Conacyt, according his academic specialization. We are considering five areas: 1)

\footnotetext{
${ }^{14}$ In a general way, the logit model could be expressed as a probalility: $\operatorname{Prob}(y=1)=\frac{1}{1+e^{-z}}$ and the equation logit as: $Z=B_{0}+B_{1} X_{1}+B_{2} X_{2}+\cdots+B_{n} X_{n}$
} 
Physics-mathematics and Earth Sciences; 2) Biology and Chemistry; 3) Medicine and Health Sciences; 6) Biotechnology and Agricultural Sciences; and 7) Engineering. We expect that the scientific research area of the researcher will influence positively the likelihood in participating as inventor either in one institutional patent, either in two or more institutional patents.

v. PhD_pncp $=$ number of $\mathrm{PhD}$ programs of each institution in the $1,2,3,4$, and 7 areas recognized by Conacyt by their academic quality recognized by the PNCP- (Quality Mexican Group of $\mathrm{PhD}$ ).

vi. claims $=$ invention scope

vii. tech_collab $=$ technological collaboration

\section{Outcomes}

According to the outcomes in this model we confirm partially our hypothesis about the factors affecting the productivity of the inventors and SNI researchers. The econometrical estimations show a significant correlation of four variables, meanwhile three variables are not statistical significant. From four individual variables selected in this model, only two have a influence in the inventors' productivity: the age and the square_age, the first in a positive sense and the second in a negative way. Also the two variables of nature invention selected: claims and tech_collab, they are positively affecting our dependent variable $\left(\right.$ pat $\left._{\text {logit }}\right)$. But, other individual variables selected as: $s n i_{2013}$ and scient_resear_area are not associated with the inventor productivity and neither the institutional variable: $P h D$ prog_pnpc, by the fact were not statistically significant.

The age variable was statistically significant ( $p$-value 0.002). Its odd ratios (15.890) suggest that a younger inventor will increase his productivity at times goes in; there is a research path that will mature his scientific and technological knowledge allowing the possibility to develop new ideas. One more year of age in average of the SNI researcher-inventor will impact positively the probability of inventor productivity in 44.14 perceptual points. But, when he gets older (the case of square_age), the odd ratio indicates the probability to participate, as inventor in one more patent grows 0.970 times. By considering that the coefficient is $<1$, the dependent variable decreases. Therefore, when the academic inventor gets oldest the probability to participate in other patent decreases in - 0.48. In that sense, we confirm our particular hypothesis.

Concerning the technological collaboration -tech_collab-is also statistically significant ( $p$-value 0.001 ). Its odd ratio indicates that the probability of have more than one patent increases 13.64 times in relation with those that do not have technological collaboration, measured by the co-patents. The logarithm of inventor productivity probability ( pat $_{\text {logit }}$ ) gets bigger 2.193 perceptual points.

In turn, the invention scope (claims) that is to say the number of novelties in the patent, as we set out, it has a positive influence on the dependent variable, having a statistical significance ( $p$-value 0.007). When there is an additional claim, according to the marginal effect, the pat ${ }_{\text {logit }}$ will increases 18.4 perceptual points.

The level of SNI researchers-inventors has not significance for the probability of increasing patents ( $p$-value 0.94). Probably, this variable is itself an indicator of productivity, therefore in this model has not the impact expected. But also, among the researchers is not been extended the patents culture and they are still more concentrated in publishing articles and books, as is 
heighted by the CONACYT SNI evaluation. Moreover, the scient_resear_area is not associated too with the inventor productivity ( $p$-value 0.29 ). Even if the scientific specialization of the SNI researcher could be crucial for development of new technological knowledge, there are some new paradigms which need researchers teams with a multidisciplinary participation; that is to say, a cognitive convergence.

Finally, $P h D$ prog_pnpc, institutional variable has not a statistical significance ( $p$-value $0)$. It has not an impact in the inventor productivity, although the joint research with $\mathrm{PhD}$ students could be important to develop new ideas. It suggests, to consider another variable more adequate, probably, the number of $\mathrm{PhD}$ students or the research projects with financial support of the own institution or other more.

All these variables are statistically significant at $5 \%$. This model was statistical consistent, in the measure that the R2 McFadden is 0.575 . The right binary classification of 0 and 1 is of $90.09 \%$.

Table 8

Outcomes of factors affecting the productivity of SNI researchers inventors

\begin{tabular}{|c|c|c|c|c|c|c|c|c|c|}
\hline & Mean & Sta. Dev. & Min. & Max. & Odd ratios & $\begin{array}{c}\text { Robust } \\
\text { standard } \\
\text { errors }\end{array}$ & $z$ & $p$ value & $\begin{array}{c}\text { Marginal } \\
\text { effects }\end{array}$ \\
\hline pat_logit & 0.35 & 0.48 & 0 & 1 & & & & & \\
\hline age_average & 45.59 & 8.05 & 28 & 76 & $15.89 * *$ & 14.139 & 3.11 & 0.002 & 44.136 \\
\hline square age & $2,133.60$ & 795.82 & 784 & 5,776 & $0.97 * *$ & 0.009 & -3.1 & 0.002 & -0.483 \\
\hline$s n i \_2013$ & 3.08 & 0.81 & 1 & 4 & 0.879 & 0.449 & -0.25 & 0.8 & -2.063 \\
\hline scient_resear_ared & 4.52 & 247 & 1 & 7 & 1.216 & 0.183 & 1.3 & 0.194 & 3.121 \\
\hline PhD prog_pnpe & 12.15 & 11.62 & 0 & 29 & 1.034 & 0.033 & 1.06 & 0.29 & 0.533 \\
\hline claims & 29.04 & 30.28 & 2 & 214 & $1.147^{* *}$ & 0.034 & 4.66 & 0 & 2.193 \\
\hline tech_collab & 0.12 & 0.32 & 0 & 1 & $13.364^{* *}$ & 12.953 & 2.67 & 0.007 & 18.463 \\
\hline Constant & & & & & 0 & 0 & -3.34 & 0.001 & - \\
\hline
\end{tabular}

$\mathrm{R}^{2}$ McFadden $=0.575$

Correctly classified $90.09 \%$

$\mathrm{N}=111$

- Significant at 5\%

\section{Conclusions}

**Significativa al $10 \%$

The econometric model used has corroborated the hypothesis in the sense that the propensity of SNI researchers to participate in the inventions patented by their institutions is marginal $(0.76 \%)$, but is higher when they belong to institutions that protect their technological innovations through patents.

Second, it has been identified that this propensity is associated with: the age and SNI level of the researchers, as personal factors; to the size of the institution and the number of doctoral programs in the PNPC, as institutional factors and, finally, the significance of the invention (measured by the number of patent citations received), the number of innovations generated (measured by the number of claims made in patents) and the technological breadth (measured by the number of technological classes), as factors of the research nature. 
In relation to the individual factors of researchers that influence the propensity of inventors to participate in inventive activity, only age and SNI level was incorporated, which reflect the researcher's career, level of education, quality of the research conducted, seniority in the institution of affiliation and gender, although business skills and the number of publications were not taken into account.

Other institutional factors that may influence the propensity of researchers to participate in inventive activities patented by the institution considered in the literature, such as the budget or financing of the institution, the strength of the intellectual property rights, the incentive system for encouraging productivity among researchers, were not included in our model out of lack of standardized information which could have been used to strengthen the estimate model. This constitutes a challenge for future research.

Lastly, access to complete information from the Mexican Institute of Intellectual Property (IMPI) could be of great help to broaden the study and quite possibly uncover new evidence.

In order to learn the magnitude of the effect of the factors that influence the propensity of SNI researchers to take part in the innovations patented by their institutions, the elasticity was estimated of the dependent variable compared to the marginal change in the independent variables. Thus, a change in SNI level increases the participation of the SNI researcher in patent matters. The propensity to patent reaches a maximum at the age of 50.11 years. A one hundredth increase in the propensity of the university to patent increases the SNI researcher's propensity to patent by nine hundredths of one patent. An increase in the number of SNI researchers in institutions will contribute to fostering and consolidating research groups, which, in turn, will encourage the creation of more patents in institutes. If the patent the researcher was involved in as an inventor is granted in an additional technological class, then the propensity of the researcher to develop innovations for his or her institution increases by nearly a quarter of one patent. The greater the collaboration between institutions will increase patenting by a third of one patent for each additional institute that collaborates.

Other variables that turned out to be statistically insignificant are: the gender variable, replaced by the variable of mixed teams and the existence of тто in universities or institutes. This first case may be due to the fact that the participation of women is greatly reduced. The second case however, reveals an almost complete lack of тто in institutions.

According to these results, с\&т policies should be aimed at encouraging more, younger researchers to join the SNI, standardization of intellectual property in the country's institutions, greater participation in technological research fields and growing the collaboration between institutions to help increase the number of inventor researchers.

Concerning the SNI -researcher- inventor productivity, we confirm partially our hypothesis. The age and the square age have influence in the inventors' productivity, the first in a positive sense and the second in a negative. Also the two variables of nature invention selected: the invention scope (claims) and technological collaborations (co-patents, as a proxy variable) are positively affecting our dependent variable $\left(\right.$ pat $_{\text {logit }}$ ). The magnitude of their effects must be considered for new policies to foster the productivity of the SNI researcher-inventors. Nevertheless, the level of SNI researcher $\left(s n i_{2013}\right)$ and the scientific area of the SNI researcherinventor (scient_resear_area) are not associated with the inventor productivity and neither the institutional variable number of $\mathrm{PhD}$ programs qualified by Conacyt PhD prog_pnpc. 
We remain with the challenge to improve the indicators that could explain in a better way how different factors could affect the productivity of the academic inventors, expecting that the research sector in Mexico favors the innovation in the industrial and service sectors, consequently, the industrial productivity and economical growth and the well-being of the population.

\section{References}

Aceytuno, M. \& Sanchéz-López, C. (2014). Carrera académica y propensión a la transferencia de tecnología. El caso de la Universidad de Huelva. Revista Investigaciones Regionales, (28): 79-100.

Agrawal, A. (2001). Common Property Institutions and Sustainable Governance of Resources. World Development, 29, 1649-1672. https://doi.org/10.1016/s0305-750x(01)00063-8

Azagra-Caro, J., Carayol, N. \& Llerena, P. (2006). Patent production at a European research university: exploratory evidence at the laboratory level. Journal of Technology Transfer, 31 (2): 257-268. https://doi.org/10.1007/s10961005-6110-3

Balconi, M., Breschi, S. \& Lissoni, F. (2004). Networks of inventors and the role of academia: an exploration of Italian patent data. Research Policy, 33(1): 127-145. https://doi.org/10.1016/s0048-7333(03)00108-2

Baldini, N. (2006). University patenting and licensing activity: a review of the literature. Research Evaluation, 15 (3): 197-207. https://doi.org/10.3152/147154406781775878

Baldini, N., Grimaldi, R. \& Sobrero, M. (2005). Institutional Changes and the Commercialization of Academic Knowledge: A Study of Italian Universities'Patenting Activities between 1965 and 2002.

Breschi, S., Lissoni, F. \& Montobbio, F. (2008). University patenting and scientific productivity: a quantitative study of Italian academic inventors, European Management Review, (5): 91-109. https://doi.org/10.1057/emr.2008.9

Calderón, G. \& García-Quevedo, J. (2012). Knowledge transfer and university patents in Mexico. Academia Revista Latinoamericana de Administración, (6): 33-60. https://doi.org/10.1108/arla-05-2013-0039

Calderón, G. (2013). La gestión de las patentes universitarias. El caso de la UNAM. Cuadernos de trabajo de la Dirección General de Evaluación Institucional, Ciudad de México: DGEI-UNAM.

Carayol, N. (2007). Academic incentives, research organization and patenting at a large French university, Economics Innovation \& New Technology, 16 (2): 119-138. https://doi.org/10.1080/10438590600982855

Colyvas, J., Crow, M., Gelijns, A., Mazzoleni, R., Nelson, R., Rosenberg, N. \& Sampat, B.N. (2002). How do university inventions get into practice? Management Science 48 (1): 61-72. https://doi.org/10.1287/mnsc.48.1.61.14272

Consejo Nacional de Ciencia y Tecnología [CONACYT]. (2013). Informe de la Ciencia y la Tecnología en México.

De Gortari, R. (1996). Los académicos: de la producción a la comercialización del conocimiento. En R. Casas \& M. Luna (Coords.), Gobierno, academia y empresas en México: hacia una nueva configuración de relaciones. México: IIS-Plaza y Valdés.

Dornbusch, F., Schmoch, U., Schulze, N. \& Bethke. N. (2013). Identification of university-based patents: A new large-scale approach. Research Evaluation, 22 (1): 52-63. https://doi.org/10.1093/reseval/rvs033

Dutrénit, G., De Fuentes, C. \& Torres, A. (2010). Channels of interaction between public research organizations and industry and their benefits: evidence from Mexico, Science and Public Policy, 37 (7): 513-526. https://doi.org/10.3152/030234210x512025

Etzkowitz, H. \& Leydesdorff. L. (1995). The triple helix-university-industry-government relations: A Laboratory for knowledge based economic development. EASST Review, (14): 14-19.

Fleming, L. \& Frenken, K. (2006). The evolution of Inventor Networks in the Silicon Valley and Boston Regions. Advances in Complex Systems, 10 (1): 53-17. https://doi.org/10.1142/s0219525907000921

Foray, D. (2007). Patents and development in the knowledge economy, ICTSD Selected Issue Briefs.

Gay, C., Lathan, W. \& Le Bas, C. (2005). Collective Knowledge, Prolific Inventors and the Value of Inventions: An Empirical Study of French, German and British Owned U.S. Patents, 1975-1998, Working Papers, number 05-16, University of Delaware, Department of Economics. 
Geuna, A. \& Nesta, L. (2006). University patenting and its effects on academic research: The emerging European evidence. Research Policy, 35 (6): 790-807. https://doi.org/10.1016/j.respol.2006.04.005

Giuri, P., Mariani, M., Brusoni, S., Crespi, G., Francoz, D., Gambardella, A., Garcia-Fontes, W., Geuna, A., Gonzales, R., Harhoff, D., Hoisl, K., Le Bas, Ch., Luzzi, A., Magazzini, L., Nesta, L., Nomaler, Ö., Palomeras, N., Patel, P., Romanelli, M. \& Verspagen, B. (2007). Inventors and invention processes in Europe: Results from the PatVal-EU survey. Research policy, 36 (8) 1107-1127. https://doi.org/10.1016/j.respol.2007.07.008

Griliches, Z., (1984). R\&D, Patents, and Productivity. Chicago: The University of Chicago Press.

Guellec, D., van Pottelsberghe, B. \& van Zeebroeck, N. (2007). Claiming more: The Increased Voluminosity of Patent Applications and its Determinants. CEPR Discussion Paper No. 5971.

Guzmán, A., Acatitla, E. \& Maldonado, K. (2015). Naturaleza y velocidad de la difusión del conocimiento tecnológico en el sector bio-farmacéutico de Brasil y México. Un análisis de citas de patentes. En M. Becerra y R. Martínez (Coords.), Tópicos de Propiedad Intelectual y Farmacéuticos en México. (pp. 221-251). México: unam- Instituto de Investigaciones Jurídicas.

Guzmán, A., Acatitla, E. \& Vázquez, T. (2016). Propensity toward industry-science links across Mexico's technological sectors: An analysis of patents, 1980-2013. Econoquantum, 13 (1): 125-157. https://doi.org/10.18381/eq. v13i1.4874

Henderson, R., Jaffe A. \& Trajtenberg, M. (1998). Universities As A Source Of Commercial Technology: A Detailed Analysis Of University Patenting, 1965-1988, The Review of Economics and Statistics, 80 (1): 119-127. https:// doi.org/10.1162/003465398557221

Huber, J. (2001). Managing Innovation Mining for Nuggets. United States of America: Authors Choice Press.

Jaffe, A. \& Lerner, J. (2007). Academic science and entrepreneurship: Dual engines of growth? Journal of Economic Behavior and Organization, 63(4): 573-576. https://doi.org/10.1016/j.jebo.2006.05.009

Jaffe, A. \& Trajtenberg, M. (2002). Patents, Citations and Innovations. Cambridge, MA: The MIT Press.

Jaffe, A., Trajtenberg, M. \& Henderson, R. (1993). Geographic Localization of Knowledge Spillovers as Evidenced by Patent Citations, The Quarterly Journal of Economics, 108 (3), 577-598. https://doi.org/10.2307/2118401

Jones, B., Reedy, E.J. \& Weinberg, B. (2014). Age and Scientific Genius. NBER Working Paper No. 19866. https://doi. org/10.3386/w19866

Lach, S. \& Shankerman, M. (2008). Incentives and invention in universities. Rand Journal of Economics, 39 (2): 403433. https://doi.org/10.1111/j.0741-6261.2008.00020.x

Libecap, Gary D. (2005). University entrepreneurship and technology transfer, Amsterdam: Elsevier.

Lissoni, F. (2012). Academic patenting in Europe: An overview of recent research and new perspectives. World Patent Information, 34 (3): 197-205. https://doi.org/10.1016/j.wpi.2012.03.002

Lissoni, F., Pezzoni, M., Poti B. \& Romagnosi, S. (2013). University autonomy, the professor privilege and academic patenting: Italy, 1996-2007. Industry and Innovation, (20): 399-421. https://doi.org/10.1080/13662716.2013.824192

Maldonado, K., Guzmán, A. \& Peredo, F. (2015). La actividad inventiva de las mujeres en Brasil, 1997-2013. Economía: Teoría y Práctica. Nueva época, Special Issue 3: 53-81. https://doi.org/10.24275/etypuam/ne/e032015/ maldonado

Morales, R. \& Sifontes, D. (2011). La actividad Innovadora por género en América Latina: un estudio de patentes. XIV Congreso Latino-Americano de Gestión Tecnológica, Perú: Altec.

Mowery, D.C. \& Sampat, B.N. (2006). Universities in National Innovation Systems. En J. Fagerberg, D. Mowery \& R. Nelson (Eds.), The Oxford Handbook of Innovation. (pp. 209-239). Cambridge, Mass: Oxford University Press.

Mowery, D.C., Nelson, R.R., Sampat, B.N. \& Ziedonis, A.A. (2004). Ivory Tower and Industrial Innovation. University-Industry Technology Transfer Before and After the Bayh-Dole Act, California: Stanford University Press.

Mowery, D.C., Sampat, B.N. \& Ziedonis, A. (2002). Learning to patent: Institutional experience, learning, and the characteristics of U. S. University Patents after the Bayh-Dole Act, 1981-92, Management Science, 48 (1): 73-89. https://doi.org/10.1287/mnsc.48.1.73.14278

Nuñez, A. \& Pedroza, A. (2011). Exploración de las capacidades de los centros públicos de investigación de México para producir y proteger nuevo conocimiento. XV Congreso Internacional de Investigación en Ciencias Administrativas, Veracruz. 
Rodeiro, D., Fernández, S., Rodríguez, A. \& Otero, L. (2012). La financiación de la investigación como motor del emprendimiento académico: análisis de las patentes universitarias. Revista de Educación, (357): 203-229.

Schmookler, J., (1962). Economic Sources of Inventive Activity, The Journal of Economic History, 22 (01), 1-20. https://doi.org/10.1017/s0022050700102311

Stezano, F. \& Millán, A. (2014). Incentivos que encuentran los académicos mexicanos para adoptar relaciones de transferencia de conocimientos y tecnología con el sector empresarial. Revista Sociológica, (83): 47-85.

Trajtenberg, M., Henderson, R., \& Jaffe, A. (2002). Patents, Citations, and Innovations: A Window on the Knowledge Economy. Cambridge, MA: MIT Press.

Trajtenberg, M., Henderson, R., \& Jaffe, A. (2002). University Versus Corporate Patents: A Window on the Basicness of Invention. En A. Jaffe, M. Trajtenberg, Patents, citations, and innovations. (pp.51-88). Cambridge Mass: MIT Press.

Urraca, A. (2005). "Patentes y Función Pública Universitaria en Europa: Mitos y Realidades". Revista Brasileira de Inovação. 4, (2): 391-423. https://doi.org/10.20396/rbi.v4i2.8648918

Walsh, J.P. \& Nagaoka, S. (2009). Who Invents?: Evidence from the Japan-U.S. inventor survey. Discussion papers from Research Institute of Economy, Trade and Industry (RIETI).

Weinberg, B., \& Galenson, D. (2005). Creative Careers: The life cycles of nobel laureates in economics. Working Paper 11799, Cambridge, MA: National Bureau of Economic Research. https://doi.org/10.3386/w11799

WIPO (2011). World Intellectual Property Report 2011. The Changing Face of Innovation, Geneva: WIPO Economics $\&$ Statistics Series.

Wolfe, D.A. (2007). El papel de la educación superior y las nuevas formas de gobernabilidad en el desarrollo económico: el caso de Ontario. En S. Yusuf \& K. Nabeshima (Eds.), Cómo promueven las universidades el crecimiento económico. (pp. 117-133). Bogotá: Banco Mundial.

Yusuf, S. \& Nabershima, K. (2007). How universities promote economic growth, Washington D.C.: The World Bank.

Zeebroeck, N., Van Pottelsberghe, B. \& Guellec, D. (2008). Patents and academic research: A state of the art. Journal of Intellectual Capital, 9 (2): 246-263. https://doi.org/10.1108/14691930810870328

Zuniga, P. (2011). The state of patenting at research institutions in developing countries: policy approaches and practices, WIPO Economic Research Working Papers. www.wipo.int/edocs/pubdocs/en/wipo_pub_econstant_wp_4.pdf

\section{Annex}

Table A1. Test Fifsat

$\begin{array}{lr}\text { fitstat } & \text { logit } \\ \text { Log-likelihood } & \\ \text { Model } & -30.337 \\ \text { Intercept-only } & -71.326 \\ \text { Chi-square } & \\ \text { Deviance (df=103) } & 60.675 \\ \text { Wald (df=7) } & 27.537 \\ \text { p-value } & 0 \\ & \\ \text { R2 } & \\ \text { McFadden } & 0.575 \\ \text { McFadden (adjusted) } & 0.463 \\ \text { McKelvey \& Zavoina } & 0.92 \\ \text { Cox-Snell/ML } & 0.522 \\ \text { Cragg-Uhler/Nagelkerke } & 0.722 \\ \text { Efron } & 0.627 \\ \text { Tjur's D } & 0.626 \\ \text { Count } & 0.901 \\ \text { Count (adjusted) } & 0.711 \\ \text { IC } & \\ \text { AIC } & 76.675 \\ \text { AiC divided by N } & 0.691 \\ \text { BiC (df } 8 \text { ) } & \\ \text { Variance of } & \\ \text { e } & \\ \text { Y-star } & \\ & \end{array}$

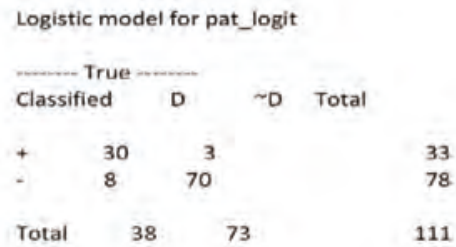

Classified + if predicted $\operatorname{Pr}(D)>=.5$ True $D$ defined as pat_logit $!=0$

Sensitivity Specificity Negative pred $\quad 89,74 \%$

False + rate fo $\quad 4.11 \%$

False - rate fo $\quad 21,05 \%$

False + rate fo $\quad 9.09 \%$

False - rate fo $\quad 10.26 \%$

Correctly classified $\quad 90.09 \%$ 